\title{
Zinc absorption in adult humans: the effect of iron fortification
}

\author{
BY LENA DAVIDSSON ${ }^{*}$, ANNETTE ALMGREN², BRITTMARIE \\ SANDSTRÖM ${ }^{3}$ AND RICHARD F. HURRELL ${ }^{1 *}$ \\ ${ }^{1}$ Nestec Ltd., Nestlé Research Centre, PO Box 44, CH-1000 Lausanne 26, Switzerland \\ ${ }^{2}$ Department of Clinical Nutrition, Gothenburg University, Annedalsklinikerna, S-41345 \\ Göteborg, Sweden \\ ${ }^{3}$ Research Department of Human Nutrition, The Royal Veterinary and Agricultural University, \\ Rolighedsvej 25, DK-1958 Fredriksberg, Denmark
}

(Received 31 May 1994 - Revised 9 January 1995 - Accepted 23 January 1995)

The effect of Fe fortification on the absorption of $\mathrm{Zn}$ was studied by radioisotopic labelling of single meals, followed by measurements of whole-body retention of ${ }^{65} \mathrm{Zn}$ at $14 \mathrm{~d}$ after intake. Healthy adult volunteers participated in the study. Weaning cereal, wheat bread and infant formula, foods that are all frequently Fe-fortified, were evaluated in the study. The amounts of $\mathrm{Fe}$ added as $\mathrm{FeSO}_{4}$ were similar to the levels in commercial products in Europe and the USA, and were 200 or $500 \mathrm{mg} \mathrm{Fe} / \mathrm{kg}$ (weaning cereal), $65 \mathrm{mg} \mathrm{Fe} / \mathrm{kg}$ (white wheat flour) and $12 \mathrm{mg} \mathrm{Fe} / \mathrm{l}$ (infant formula). For comparison, $\mathrm{Zn}$ absorption was measured in the same subjects, from identical test meals containing no added Fe. No statistically significant differences were found when $\mathrm{Zn}$ absorption from the Fe-fortified test meals was compared with that from non-Fe-fortified test meals. Fractional $\mathbf{Z n}$-absorption values from $\mathbf{F e}$-fortified v. non-fortified meals were 31.1 (SD 11.9) v. 30.7 (SD 7.0) \% (weaning cereal; $200 \mathrm{mg} \mathrm{Fe} / \mathrm{kg}$ ), 37.7 (SD 16.6) v. 30.2 (SD 9.9) \% (weaning cereal; $500 \mathrm{mg} \mathrm{Fe} / \mathrm{kg}$ ), 36.5 (SD 14.4) v. 38.2 (SD 18.1)\% (bread; $65 \mathrm{mg}$ $\mathrm{Fe} / \mathrm{kg}$ flour) and 41.6 (SD 8-1) v. 38.9 (SD 14.5)\% (infant formula; $12 \mathrm{mg} \mathrm{Fe} / \mathrm{l}$ ). The addition of $\mathrm{Fe}$ to foods at the currently used fortification levels was thus not associated with impaired absorption of $\mathrm{Zn}$ and the consumption of these Fe-fortified foods would not be expected to have a negative effect on $\mathrm{Zn}$ nutrition.

Zinc: Iron: Humans: Radioisotope

Fe deficiency is one of the major nutritional problems in the world today, primarily affecting fertile women, infants and children (Bothwell et al. 1979; DeMaeyer \& AdielsTegman, 1985). The major causative factors are low dietary intake as well as low bioavailability of $\mathrm{Fe}$ in the diet, in particular in the largely cereal-based diets in many developing countries (Charlton \& Bothwell, 1983; Layrisse et al. 1990). One way of overcoming this problem is by increasing the intake of $\mathrm{Fe}$, for example by fortification of foods regularly consumed by the groups at risk. This method is generally considered to be the best long-term strategy for reducing the prevalence of Fe deficiency (International Nutritional Anemia Consultative Group, 1977; Cook \& Reusser, 1983). However, concern has sometimes been raised as to whether the increased intake of $\mathrm{Fe}$, via food fortification programmes, could have a negative effect on the absorption of other minerals, in particular $\mathrm{Zn}$ (for a review see Solomons, 1986). A negative effect of increased Fe content on $\mathrm{Zn}$ absorption has been reported from studies in humans using the plasma response test after intake of water solutions, or Coca Cola, with high Zn concentrations (Solomons \& Jacob, 1981; Solomons et al. 1983; Crofton et al. 1989). Later studies, using a radionuclide

* Present address: Laboratory for Human Nutrition, Swiss Federal Institute of Technology, PO Box 474, CH-8803 Rüschlikon, Switzerland. 
technique based on whole-body retention measurements and with more 'physiological' levels of $\mathrm{Zn}$ present, confirmed the inhibitory effect of $\mathrm{Fe}$ on $\mathrm{Zn}$ absorption from water solutions (Sandström et al. 1985). However, when the Fe content of foods (as opposed to water solutions) was increased, no negative effect on $\mathrm{Zn}$ absorption was found (Solomons \& Jacob, 1981; Valberg et al. 1984; Sandström et al. 1985). It can thus be argued that the increased Fe content of foods, from Fe-fortification, is of no concern for the absorption of $\mathrm{Zn}$ from the diet. However, the test meals used in the studies consisted of Atlantic oysters (Solomons \& Jacob, 1981), turkey meat (Valberg et al. 1984) or rice and meat sauce (Sandström et al. 1985), none of which is representative of foods normally fortified with Fe. Furthermore, for groups of the population where Fe-fortified foods form a large fraction of the total intake of energy and nutrients, the issue about whether an increased intake of Fe could influence $\mathrm{Zn}$ nutrition negatively is of importance. Of special interest is the situation for infants who consume a limited number of foods of which a large proportion is usually Fe-fortified (infant formula and cereals) and for whom $\mathrm{Zn}$ is needed due to the rapid growth early in life (Walravens \& Hambidge, 1975; Golden \& Golden, 1981; Walravens et al. 1983, 1989).

The present study was undertaken to evaluate further the effect of increased Fe intake from Fe-fortified foods on the absorption of $\mathrm{Zn}$. $\mathrm{Zn}$ absorption from test meals fortified with $\mathrm{Fe}$ was measured in healthy adult volunteers by a radionuclide technique. Comparisons were made with identical test meals without extra $\mathrm{Fe}$ added. The test meals evaluated in this study consisted of weaning cereal, wheat flour (served as bread) and infant formula.

\section{MATERIALS AND METHODS}

\section{Subjects}

Forty healthy adult volunteers (twenty-eight women and twelve men; 19-38 years) participated in four separate $\mathrm{Zn}$-absorption studies. Eight subjects participated in studies 1,3 and 4 while in study 2 there were sixteen subjects. All were apparently healthy, nonpregnant, and without known gastrointestinal disorders. The subjects were given oral and written information about the aims and procedures of the study.

\section{Zinc-absorption measurements}

$\mathrm{Zn}$ absorption was measured according to the method of Arvidsson et al. (1978). Each subject's background radioactivity was measured before intake of the labelled test meal. The subjects were randomly allocated to the different test meals which were served after an overnight fast. No food or drink was allowed for $3 \mathrm{~h}$ after intake of the test meals. The whole-body retention was measured $10-14 \mathrm{~d}$ after intake of each test meal to allow for excretion of the non-absorbed fraction. Corrections were made for the excretion of initially absorbed isotope during the time between intake and retention measurements based on the mean rate of excretion of an intravenously administered dose of ${ }^{65} \mathrm{Zn}$ in a similar group of subjects (Arvidsson et al. 1978). After intake of the second test meal (approximately $14 \mathrm{~d}$ after intake of the first test meal), allowance was also made for the excretion of the residual radioactivity from the first test meal.

\section{Test meals}

The composition of the test meals is given in Table 1. The wheat flour and weaning cereal were prepared at a Nestlé Product Development Centre (Linor, Orbe, Switzerland).

Studies 1 and 2. A pre-cooked, roller-dried weaning cereal based on white wheat flour was prepared especially for the study without added $\mathrm{Fe}$ or vitamins. The cereal contained $858 \mathrm{~g}$ wheat flour $/ \mathrm{kg}, 100 \mathrm{~g}$ sugar $/ \mathrm{kg}$ and $\mathrm{CaCO}_{3}$ was added at a level of $1.8 \mathrm{~g} / \mathrm{kg}$ final 
Table 1. Composition of test meals, amount of iron added, level of iron fortification and iron: zinc ratio in the separate test meals

\begin{tabular}{|c|c|c|c|c|c|}
\hline Study & Ingredients & Test meal (a) & $\begin{array}{c}\mathrm{Fe}: \mathrm{Zn} \\
\text { ratio }\end{array}$ & Test meal (b) & $\begin{array}{l}\mathrm{Fe}: \mathrm{Zn} \\
\text { ratio }\end{array}$ \\
\hline 1 & $\begin{array}{l}\text { Weaning cereal }(50 \mathrm{~g}) \\
\text { Milk }(325 \mathrm{~g}) \\
\text { Water }(150 \mathrm{~g})\end{array}$ & $\begin{array}{c}10 \mathrm{mg} \mathrm{Fe} \\
(200 \mathrm{mg} \mathrm{Fe} / \mathrm{kg})\end{array}$ & $23 \cdot 3: 1$ & No Fe added & $0 \cdot 57: 1$ \\
\hline 2 & $\begin{array}{l}\text { Weaning cereal }(50 \mathrm{~g}) \\
\text { Milk }(325 \mathrm{~g}) \\
\text { Water }(150 \mathrm{~g})\end{array}$ & $\begin{array}{c}25 \mathrm{mg} \mathrm{Fe} \\
(500 \mathrm{mg} \mathrm{Fe} / \mathrm{kg})\end{array}$ & $57 \cdot 4: 1$ & No Fe added & $0.57: 1$ \\
\hline 3 & $\begin{array}{l}\text { Bread rolls }(60 \mathrm{~g} \text { flour }) \\
\text { Butter }(10 \mathrm{~g}) \\
\text { Water }(200 \mathrm{~g})\end{array}$ & $\begin{array}{c}3.9 \mathrm{mg} \mathrm{Fe} \\
(65 \mathrm{mg} \mathrm{Fe} / \mathrm{kg})\end{array}$ & $8 \cdot 8: 1$ & No Fe added & $1 \cdot 2: 1$ \\
\hline 4 & Infant formula $(450 \mathrm{~g})$ & $\begin{array}{c}5.4 \mathrm{mg} \mathrm{Fe} \\
(12 \mathrm{mg} \mathrm{Fe} / 1)\end{array}$ & $10 \cdot 2: 1$ & No Fe added & $0 \cdot 17: 1$ \\
\hline
\end{tabular}

product. Each serving consisted of $50 \mathrm{~g}$ cereal mixed with $325 \mathrm{~g}$ hot milk $(30 \mathrm{~g}$ fat $/ 1)$. The subjects were served $150 \mathrm{~g}$ ultra pure water (18 M omega; Milli-Q water system, Millipore $\mathrm{AG}$, Zurich, Switzerland) together with the hot cereal meal. Fe was added to the cereal at the time of serving, corresponding to $200 \mathrm{mg}$ (study 1) or $500 \mathrm{mg} \mathrm{Fe} / \mathrm{kg}$ cereal (study 2). Wheat flour $(5.3 \mathrm{~g}$ ash $/ \mathrm{kg}$ ) was used for production of the weaning cereal, as well as for preparing the bread rolls served in study 3 .

Study 3. Dough was prepared from wheat flour, ultra pure water, salt and yeast. Rolls were made from weighed amounts of dough, each corresponding to $30 \mathrm{~g}$ wheat flour. Each test meal consisted of two bread rolls ( $60 \mathrm{~g}$ flour) served with $200 \mathrm{~g}$ ultra pure water and $10 \mathrm{~g}$ butter, Fe was added at a level of $65 \mathrm{mg} \mathrm{Fe} / \mathrm{kg}$ flour during preparation of the dough.

Study 4. A commercial cow's milk-based, whey-adjusted infant formula without added Fe (Nestlé, Germany) was used in study 4 . The test meal consisted of $450 \mathrm{~g}$ infant formula with or without $\mathrm{Fe}$ added at $12 \mathrm{mg} / \mathrm{l}$.

Fe was added as food-grade $\mathrm{FeSO}_{4} .7 \mathrm{H}_{2} \mathrm{O}$ (Merck, Darmstadt, Germany) to all Fefortified test meals. Each test meal was extrinsically labelled with $0.05 \mathrm{MBq}{ }^{65} \mathrm{Zn}$ (first test meal) or $0.1 \mathrm{MBq}{ }^{65} \mathrm{Zn}$ (second test meal) by adding almost carrier-free ${ }^{65} \mathrm{ZnCl}_{2}$ solution (3.2-92.5 MBq/mg $\mathrm{Zn}$; Amersham International, Bucks) during preparation of the test meals. The effective dose equivalent was calculated for each subject according to the data given by the International Commission on Radiological Protection (1987) and based on individual $\mathrm{Zn}$-absorption values. Bread rolls were labelled by adding the isotope to the dough, while the hot cereal was labelled immediately before serving due to practical considerations. The infant formula was labelled about $16 \mathrm{~h}$ before consumption. The activity of each individual test meal was measured in the whole-body counter before being served. All administrations of labelled test meals were done under close supervision by one of the investigators to ensure that the entire serving was consumed. Leftovers were measured in the whole-body counter after intake in order to calculate the exact dose of radioactivity consumed by each subject. 
Table 2. Contents of nitrogen, calcium, zinc and iron in weaning cereal, wheat flour and infant formula, before iron fortification

\begin{tabular}{lcccc}
\hline \hline & $\begin{array}{c}\text { Nitrogen } \\
(\mathrm{g})\end{array}$ & $\begin{array}{c}\text { Calcium } \\
(\mathrm{mg})\end{array}$ & $\begin{array}{c}\text { Zinc } \\
(\mathrm{mg})\end{array}$ & $\begin{array}{c}\text { Iron } \\
(\mathrm{mg})\end{array}$ \\
\hline Weaning cereal $(50 \mathrm{~g})$ & 1.1 & 16.5 & 0.44 & 0.27 \\
Wheat flour $(60 \mathrm{~g})$ & 1.3 & 12.5 & 0.51 & 0.60 \\
Infant formula (450 g) & 1.2 & 227 & 0.54 & 0.09 \\
\hline
\end{tabular}

\section{Food analysis}

Portions of the foods were analysed in duplicate for their content of $\mathrm{Fe}, \mathrm{Ca}$ and $\mathrm{Zn}$ by atomic absorption spectrometry (AAS : model 975, Varian Techtron, Mulgrave, Australia). Samples of wheat flour and infant cereal were wet-ashed in silica flasks with a mixture of $\mathrm{HNO}_{3}$ and $\mathrm{H}_{2} \mathrm{O}_{2}$ on a continuous wet-ashing system (VAO, Kürner Analysentechnik, Rosenheim, Germany). Samples of the infant formula were ashed in silica Ehrlenmeyer flasks in a muffle furnace at $510^{\circ}$ for $48 \mathrm{~h}$. Ash was dissolved in $4 \mathrm{ml}$ concentrated $\mathrm{HCl}$ and diluted to $25 \mathrm{ml}$ with ultra pure water. For $\mathrm{Ca}$ analysis, $\mathrm{La}_{2} \mathrm{O}_{3}$ was added to the mineralized samples equivalent to a final concentration of $10 \mathrm{~g} / 1$. Fe was analysed by graphite furnace AAS, using the model 975 AAS equipped with a GTA-95 graphite furnace and an auto sampler. Accuracy of the methods was tested by analysing the standard reference materials Wheat Flour (1567a) and Milk Powder (M1549; National Institute of Standards and Technology, Gaithersburg, MD, USA). Freeze-dried samples of milk were analysed for their content of $\mathrm{Zn}$ and $\mathrm{Ca}$ by AAS (Perkin Elmer Model 360, Perkin Elmer, Uberlingen, Germany) after dry- and wet-ashing respectively. Reference materials purchased from the National Bureau of Standards (Gaithersburg and Washington DC: Mixed Diet 8431, Bovine Liver 1577a and Orchard Leaves 157) were analysed together with the milk samples. $\mathrm{N}$ was analysed by the Kjeldahl technique.

Only ultra pure water was used during analysis.

\section{Statistical analysis}

Student's $t$ test for paired observations was used for statistical comparisons.

\section{Ethical considerations}

The study was approved by the Research Ethical Committee and the Isotope Committee at Sahlgren's Hospital, Göteborg, Sweden.

\section{RESULTS}

The contents of $\mathrm{N}, \mathrm{Ca}, \mathrm{Zn}$ and $\mathrm{Fe}$ in the weaning cereal, wheat flour and infant formula, before the addition of Fe, are given in Table 2 . Milk ( $30 \mathrm{~g}$ fat $/ 1)$ added to the weaning cereal contained $1.6 \mathrm{~g} \mathrm{~N}, 380 \mathrm{mg} \mathrm{Ca}$ and $1.3 \mathrm{mg} \mathrm{Zn/325} \mathrm{g}$. All values for the reference materials were found to be within the certified ranges.

$\mathrm{Zn}$ absorption from the different test meals showed no statistically significant difference related to the $\mathrm{Fe}$ content of the foods. $\mathrm{Zn}$ absorption from weaning cereal $(200 \mathrm{mg} \mathrm{Fe} / \mathrm{kg})$ served with milk was 31.1 (SD 11.9) v. 30.7 (SD 7.0) \% when no Fe was added. The same weaning cereal studied at a higher Fe-fortification level $(500 \mathrm{mg} \mathrm{Fe} / \mathrm{kg}$ ) resulted in $\mathrm{Zn}$ absorption of 37.7 (SD 16.6) v. 30.2 (SD 9.9) \% when no Fe was added. Wheat bread fortified at $65 \mathrm{mg} \mathrm{Fe} / \mathrm{kg}$ flour resulted in $\mathrm{Zn}$ absorption of 36.5 (SD 14.4) v. 38.2 (SD 18.1) \% for non- 
Table 3. Study 1. Individual zinc-absorption values for weaning cereal

\begin{tabular}{|c|c|c|c|}
\hline \multirow[b]{2}{*}{ Subject } & \multirow[b]{2}{*}{ Sex } & \multicolumn{2}{|c|}{ Zn absorption (\%) } \\
\hline & & $\begin{array}{l}\text { Weaning cereal (a) } \\
(200 \mathrm{mg} \mathrm{Fe} / \mathrm{kg})\end{array}$ & $\begin{array}{l}\text { Weaning cereal (b) } \\
\text { (no added } \mathrm{Fe} \text { ) }\end{array}$ \\
\hline 1 & $\mathrm{~F}$ & $30 \cdot 7$ & $24 \cdot 5$ \\
\hline 2 & $\mathbf{M}$ & $44 \cdot 8$ & $33 \cdot 5$ \\
\hline 3 & $\mathrm{~F}$ & $23 \cdot 0$ & $33 \cdot 4$ \\
\hline 4 & $\mathbf{M}$ & $33 \cdot 4$ & $29 \cdot 6$ \\
\hline 5 & $\mathrm{~F}$ & $26 \cdot 8$ & $25 \cdot 3$ \\
\hline 6 & M & $20 \cdot 2$ & $27 \cdot 1$ \\
\hline 7 & $\mathbf{F}$ & $51 \cdot 7$ & $45 \cdot 8$ \\
\hline 8 & $\mathbf{F}$ & $18 \cdot 3$ & $26 \cdot 5$ \\
\hline Mean & & $31 \cdot 1$ & $30 \cdot 7$ \\
\hline SD & & 11.9 & $7 \cdot 0$ \\
\hline
\end{tabular}

Table 4. Study 2. Individual zinc-absorption values for weaning cereal

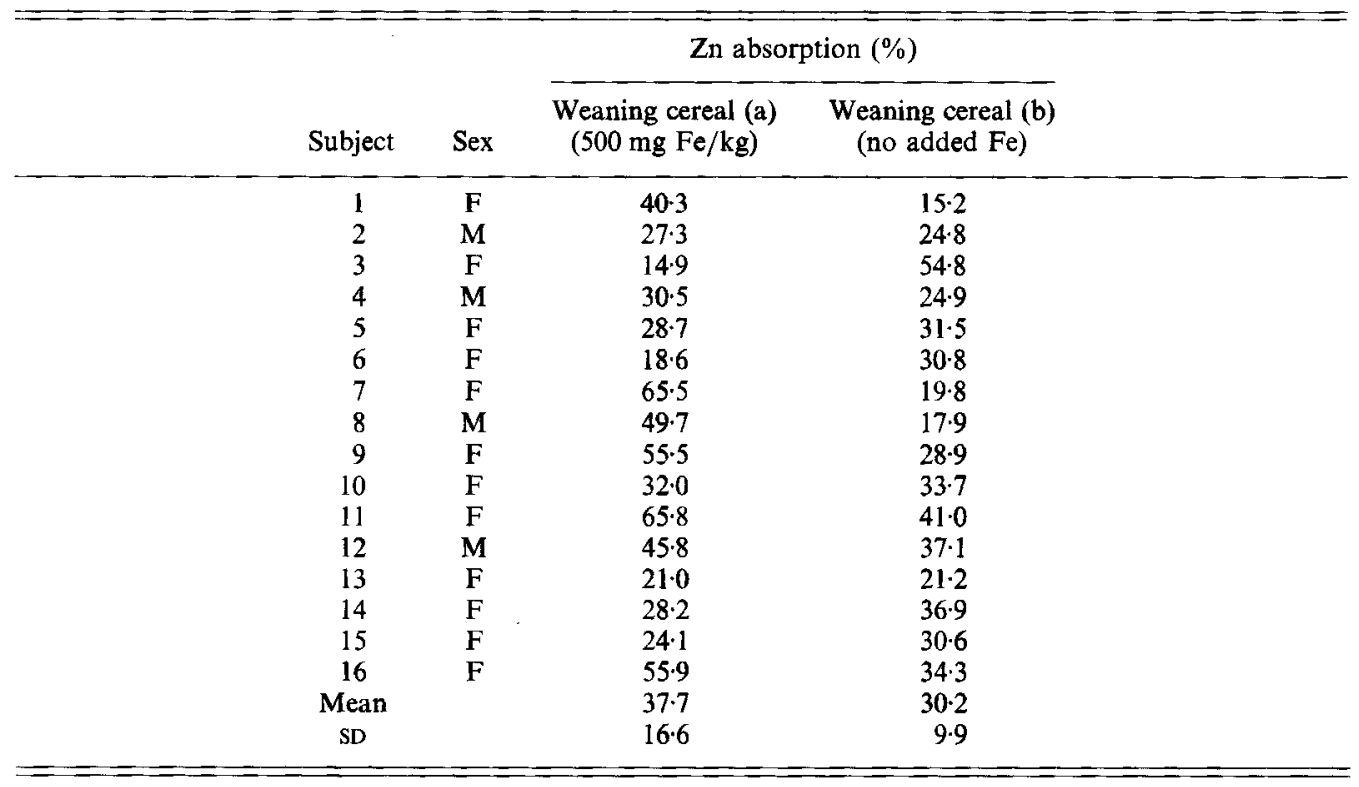

Fe-fortified bread. The $\mathrm{Zn}$ absorption from infant formula was also unaffected by the level of Fe-fortification; 41.6 (SD 8.1) v. 38.9 (SD 14.5) \% was absorbed from formula containing $12 \mathrm{mg} \mathrm{Fe} / 1$ compared with when no $\mathrm{Fe}$ was added. The fractional $\mathrm{Zn}$-absorption values for each subject are given in Tables 3-6.

The mean effective dose equivalent was calculated to be $0.57 \mathrm{mSv}$ (range $0.25-0.97 \mathrm{mSv}$ ) per subject.

\section{DISCUSSION}

Mild $\mathrm{Zn}$ deficiency has been related to poor growth early in life since a positive effect of $\mathrm{Zn}$ supplementation has been demonstrated in infants and preschool children (Walravens et al. 1983, 1989). It is thus very important to ensure that $\mathrm{Zn}$ absorption from foods normally 
Table 5. Study 3. Individual zinc-absorption values for bread rolls

\begin{tabular}{|c|c|c|c|}
\hline \multirow[b]{2}{*}{ Subject } & \multirow[b]{2}{*}{ Sex } & \multicolumn{2}{|c|}{$\mathrm{Zn}$ absorption (\%) } \\
\hline & & $\begin{array}{c}\text { Bread rolls (a) } \\
(65 \mathrm{mg} \mathrm{Fe} / \mathrm{kg} \text { flour })\end{array}$ & $\begin{array}{l}\text { Bread rolls (b) } \\
\text { (no added } \mathrm{Fe} \text { ) }\end{array}$ \\
\hline 1 & $\mathbf{F}$ & $51-2$ & $73 \cdot 9$ \\
\hline 2 & $\mathrm{~F}$ & $50 \cdot 3$ & $42 \cdot 4$ \\
\hline 3 & $\mathbf{M}$ & $32 \cdot 7$ & $41 \cdot 4$ \\
\hline 4 & $\mathbf{F}$ & $15 \cdot 8$ & $14 \cdot 6$ \\
\hline 5 & $\mathbf{F}$ & $21 \cdot 2$ & $26 \cdot 0$ \\
\hline 6 & $\mathbf{M}$ & $27 \cdot 5$ & $29 \cdot 7$ \\
\hline 7 & $\mathrm{~F}$ & $40 \cdot 2$ & $48 \cdot 8$ \\
\hline 8 & $\mathbf{M}$ & $53 \cdot 2$ & $28 \cdot 5$ \\
\hline Mean & & $36 \cdot 5$ & $38 \cdot 2$ \\
\hline SD & & $14 \cdot 4$ & $18 \cdot 1$ \\
\hline
\end{tabular}

Table 6. Study 4. Individual zinc-absorption values for infant formula

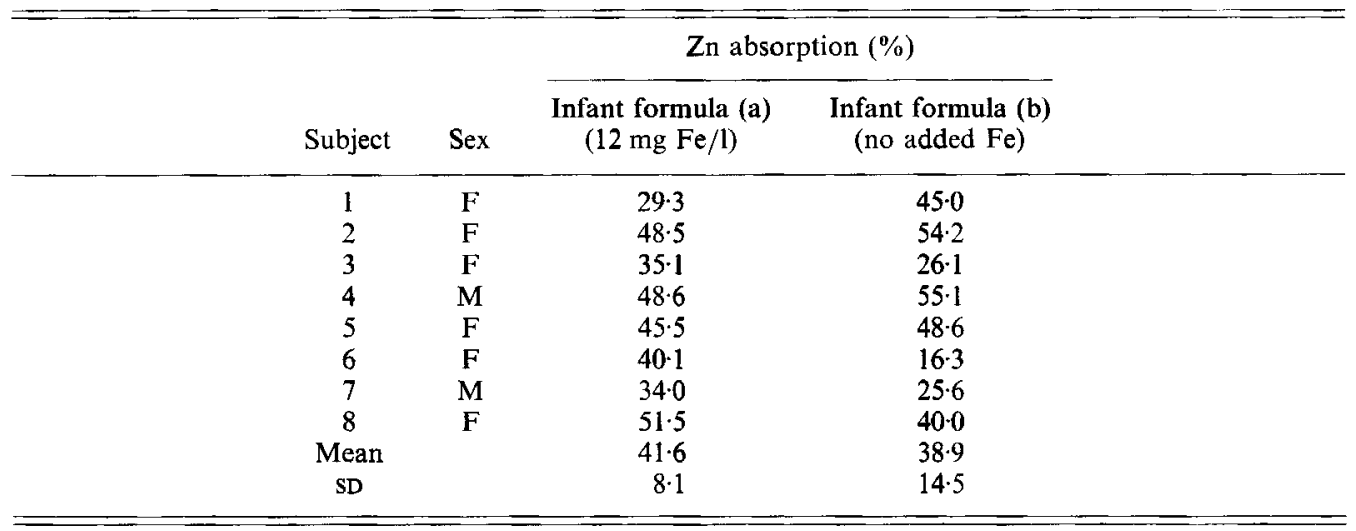

consumed by infants and young children, e.g. infant formulas and weaning cereals, is optimal. Since these foods are commonly fortified with Fe it was considered important to evaluate the effect of $\mathrm{Fe}$ fortification on $\mathrm{Zn}$ absorption.

The results from the present study confirm the earlier observations that, although $\mathrm{Fe}$ inhibits $\mathrm{Zn}$ absorption from water solutions, an increased $\mathrm{Fe}$ content in foods does not impair $\mathrm{Zn}$ absorption (Valberg et al. 1984; Sandström et al. 1985). The difference between water solutions and more complex matrices containing dietary ligands, such as foods, is also demonstrated by the results from the study by Sandström et al. (1985) where the addition of a $\mathrm{Zn}$-ligand, histidine, to the water solution decreased the inhibitory effect of Fe. In a similar study by Rossander-Hultén et al. (1991), looking at the effect of high $\mathrm{Zn}$ levels on $\mathrm{Fe}$ absorption, a strong negative effect on $\mathrm{Fe}$ absorption was found when increased amounts of $\mathrm{Zn}$ were added to water solutions, while no effect was observed when the test meal consisted of a composite meal. These results taken together thus suggest that when dietary ligands are present, either in foods or by addition to water solutions, there is little or no interaction between the absorption of $\mathrm{Fe}$ and $\mathrm{Zn}$. A negative effect on $\mathrm{Zn}$ absorption due to increased Fe intake from foods, via Fe-fortification compounds, would 
therefore not be expected. The effect of considerably higher Fe intakes on $\mathrm{Zn}$ nutrition, for example in the form of dietary supplements, has been investigated in some recent studies. Decreased concentrations of $\mathrm{Zn}$ in serum were found in Fe-supplemented pregnant women (Bloxam et al. 1989; Dawson et al. 1989) as well as in non-pregnant women (Newhouse et al. 1993).

The Fe compound used to fortify foods in the present study was $\mathrm{FeSO}_{4}$. This compound is commonly used to fortify infant formulas and occasionally used to fortify bread and wheat flour which is stored for short periods of time (Hurrell, 1992). When added to weaning cereals, $\mathrm{FeSO}_{4}$ causes fat oxidation during storàge and also causes unwanted colour reactions. $\mathrm{FeSO}_{4}$ added to wheat flour or other cereals promotes fat oxidation during long-term storage, which leads to rancid products. Wheat flour and weaning cereals are consequently often fortified with elemental $\mathrm{Fe}$, ferric orthophosphate or ferric pyrophosphate (Hurrell, 1992). Other Fe-fortified foods commonly consumed by children, such as breakfast cereals and chocolate drink powder, are also normally fortified with the same compounds. These $\mathrm{Fe}$ compounds are less soluble in the gastric juice and less bioavailable than $\mathrm{FeSO}_{4}$ and would be expected to have even less effect on $\mathrm{Zn}$ absorption. Furthermore, the level of Fe-fortification varies between different products and also between different countries (Lynch \& Hurrell, 1990). In the present study we used the higher levels of commonly practised Fe-fortification, i.e. $65 \mathrm{mg} \mathrm{Fe} / \mathrm{kg}$ wheat flour as used in Sweden and $12 \mathrm{mg} \mathrm{Fe} / 1$ infant formula which is the content of $\mathrm{Fe}$ in infant formulas in the USA. The cereal was evaluated at the current level of Fe-fortification in both European and US commercial weaning cereal; 200 and $500 \mathrm{mg} \mathrm{Fe} / \mathrm{kg}$ cereal. The test meals in the present study therefore represent a more stressed situation than normally present in Fefortified foods, i.e. a highly bioavailable Fe compound was added at relatively high levels. Therefore, it is not very likely that $\mathrm{Zn}$ absorption would be influenced by the commonly used Fe-fortification practices.

The present study, as well as earlier studies, have used adult human subjects because radioisotopes were administered. Both men and women were included in the studies since no sex differences in $\mathrm{Zn}$ absorption have been reported to our knowledge. The radionuclide technique used in the present study has been described in detail (Arvidsson et al. 1978). The $100 \%$ dose of radioactivity ingested by each subject was calculated as the difference between the measured activity in the test meal, minus activity in the leftovers measured after administration. Alternatively, subjects could be measured in the whole-body counter immediately after intake of the labelled test meals. We did not choose the latter approach due to the uneven distribution of the ingested isotope shortly after intake. Immediately after ingestion of the labelled test meal the dose of radioactivity must still be regarded as a point source, surrounded by the body. The systematic error introduced by measuring the point source before administration compared with measurements after ingestion has been estimated to be a maximum of $10 \%$ (A. Cederblad, personal communication, 1994). The error is relatively small due to the characteristics of the whole-body counter used in our studies. Large detectors and the choice of using the 'valley' spectral window are important features of this whole-body counter (Arvidsson et al. 1978).

Since infants and children are among the most vulnerable groups to be affected by impaired absorption of dietary $\mathrm{Zn}$, it still remains to confirm that Fe-fortification has no effect on $\mathrm{Zn}$ absorption in this age group. Stable-isotope techniques are now available making it possible to measure $\mathrm{Zn}$ absorption in infants, but due to the much more elaborate study protocol needed, i.e. complete faecal collections over several days, this has not yet been done. The results from a metabolic balance study in infants (Haschke et al. 1986) did not demonstrate any effect of Fe-fortification in infant formulas $(2 \cdot 5 v .10 \cdot 2 \mathrm{mg} \mathrm{Fe} / \mathrm{l})$ on $\mathrm{Zn}$ absorption. 
Long-term effects on $\mathrm{Zn}$ status of the consumption of Fe-fortified foods have not been addressed in the present study. In several other studies this issue has been investigated without finding any influence. For example, no significant effect on the level of $\mathrm{Zn}$ in serum in infants could be related to the Fe-content of the infant formulas fed in the study by Bradley et al. (1993), and in a study of low-birthweight infants by Salvioli et al. (1986) the addition $\mathrm{Fe}$ given as medicinal $\mathrm{Fe}$, together with $\mathrm{Fe}$-fortified formula, did not influence plasma $\mathrm{Zn}$ levels. Furthermore, no effect on serum $\mathrm{Zn}$ levels was observed after 3 months of Fe-supplementation in the form of $30 \mathrm{mg} \mathrm{Fe} /$ day, administered in close proximity to breakfast to 1-year-old children (Yip et al. 1985). However, Craig et al. (1984) reported significantly lower plasma $\mathrm{Zn}$ levels in a small group of infants given Fe-fortified formula, compared with low-Fe formula. Thus, while there are no conclusive data on the long-term effects of an increased $\mathrm{Fe}$ intake on $\mathrm{Zn}$ nutrition in infants, the results from most studies have not demonstrated any negative effect.

In conclusion, $\mathrm{Zn}$ absorption was not affected by the increased content of $\mathrm{Fe}$ in foods, when added at commonly used levels for Fe-fortification in the present study. Thus, the consumption of $\mathrm{Fe}$-fortified foods does not appear to influence $\mathrm{Zn}$ nutrition negatively.

\section{REFERENCES}

Arvidsson, B., Cederblad, A., Björn-Rasmussen, E. \& Sandström, B. (1978). A radionuclide technique for studies of zinc absorption in man. International Journal of Nuclear Medicine and Biology 5, 104-109.

Bloxam, D. L., Williams, N. R., Waskett, R. J., Pattison-Green, P. M., Morarji, Y. \& Stewart, S. G. (1989). Maternal zinc during oral iron supplementation in pregnancy: a preliminary study. Clinical Science 76, 59-65.

Bothwell, T. H., Charlton, R. W., Cook, J. D. \& Finch, C. A. (1979). Iron Metabolism in Man. Oxford: Blackwell Scientific.

Bradley, C. K., Hillman, L., Sherman, A. R., Leedy, D. \& Cordano, A. (1993). Evaluation of two iron-fortified milk-based formulas during infancy. Pediatrics $91,908-914$.

Charlton, R. W. \& Bothwell, T. H. (1983). Iron absorption. Annual Review of Medicine 34, 55-68.

Cook, J. D. \& Reusser, M. (1983). Iron fortification; an update. American Journal of Clinical Nutrition 38, 648-659.

Craig, W. J., Balbach, L., Harris, S. \& Vyhmeister, N. (1984). Plasma zinc and copper levels of infants fed different milk formulas. Journal of the American College of Nutrition 3, 183-186.

Crofton, R. W., Gvozdanovic, D., Gvozdanovic, S., Khin, C. C., Brunt, P. W., Mowat, N. A. G. \& Aggett, P. J. (1989). Inorganic zinc and intestinal absorption of ferrous iron. American Journal of Clinical Nutrition 50, 141-144.

Dawson, E. B., Albers, J. \& McGanity, W. J. (1989). Serum zinc changes due to iron supplementation in teen-age pregnancy. American Journal of Clinical Nutrition 50, 848-852.

DeMaeyer, E. \& Adiels-Tegman, M. (1985). The prevalence of anaemia in the world. World Health Statistics Quarterly 38, 302-316.

Golden, B. E. \& Golden, M. H. N. (1981). Plasma zinc, rate of weight gain, and the energy cost of tissue deposition in children recovering from severe malnutrition on a cow's milk or soya protein based diet. American Journal of Clinical Nutrition 34, 892-899.

Haschke, F., Ziegler, E. E., Edwards, B. B. \& Fomon, S. J. (1986). Effect of iron fortification of infant formula on trace mineral absorption. Journal of Pediatric Gastroenterology and Nutrition 5, 768-773.

Hurrell, R. F. (1992). Prospects for improving the iron fortification of foods. In Nutritional Anemias, pp. 193-208 [S. J. Fomon and S. Zlotkin, editors]. New York: Raven Press, Ltd.

International Commission on Radiological Protection (1987). ICRP publication 53, Radiation dose to patients from radiopharmaceuticals. Annals of the ICRP $18(1-4)$.

International Nutritional Anemia Consultative Group (1977). Guidelines for the Eradication of Iron Deficiency Anemia. New York: Nutrition Foundation.

Layrisse, M., Martinez-Torres, C., Mendez-Castellano, H., Taylor, P., Fossi, M., Lopez de Blanco, M., LandaetaJimez, M., Jaffe, W., Leets, I., Tropper, E., Garcia-Casal, M. N. \& Ramirez, J. (1990). Relationship between iron bioavailability from diets and prevention of iron deficiency. Food Nutrition Bulletin 12, 301-309.

Lynch, S. R. \& Hurrell, R. F. (1990). Iron in formulas and baby foods. In Iron Metabolism in Infants, pp. $109-126$ [B. Lönnerdal, editor]. Boca Raton: CRC Press, Inc.

Newhouse, 1. J., Clement, D. B. \& Lai, C. (1993). Effects of iron supplementation and discontinuation on serum copper, zinc, calcium, and magnesium levels in women. Medicine and Science in Sports and Exercise 25, 562-571.

Rossander-Hultén, L., Brune, M., Sandström, B., Lönnerdal, B. \& Hallberg, L. (1991). Competitive inhibition of iron absorption by manganese and zinc in humans. American Journal of Clinical Nutrition 54, 152-156. 
Salvioli, G. P., Faldella, G., Alessandroni, R., Lanari, M. \& Benefenati, L. (1986). Plasma zinc concentrations in iron supplemented low birthweight infants. Archives of Disease in Childhood 61, 346-348.

Sandström, B., Davidsson, L., Cederblad, A. \& Lönnerdal, B. (1985). Oral iron, dietary ligands and zinc absorption. Journal of Nutrition 115, 411-414.

Solomons, N. W. (1986). Competitive interaction of iron and zinc in the diet : consequences for human nutrition. Journal of Nutrition 116, 927-935.

Solomons, N. W. \& Jacob, R. A. (1981). Studies on the bioavailability of zinc in humans: effects of heme and nonheme iron on the absorption of zinc. American Journal of Clinical Nutrition 34, 475-482.

Solomons, N. W., Pineda, O., Viteri, F. \& Sandstead, H. H. (1983). Studies on the bioavailability of zinc in humans: mechanism of the intestinal interaction of nonheme iron and zinc. Journal of Nutrition 113, 337-349.

Valberg, L. S., Flanagan, P. R. \& Chamberlain, M. J. (1984). Effects of iron, tin, and copper on zinc absorption in humans. American Journal of Clinical Nutrition 40, 536-541.

Walravens, P. A. \& Hambidge, K. M. (1976). Growth of infants fed a zinc-supplemented formula. American Journal of Clinical Nutrition 29, 1114-1121.

Walravens, P. A., Hambidge, K. M. \& Koepfer, D. M. (1989). Zinc supplementation in infants with a nutritional pattern of failure to thrive: a double-blind, controlled study. Pediatrics 83, 532-538.

Walravens, P. A., Krebs, N. F. \& Hambidge, K. M. (1983). Linear growth of low income preschool children receiving a zine supplement. American Journal of Clinical Nutrition 38, 195-201.

Yip, R., Reeves, J. D., Lönnerdal, B., Keen, C. L. \& Dallman, P. R. (1985). Does iron supplementation compromise zinc nutrition in healthy infants? American Journal of Clinical Nutrition 42, 683-687. 